\title{
An assessment for diagnostic and therapeutic modalities for management of pediatric Iron defficiency Anemia in Saudi Arabia: a crossectional study
}

Hadi J. Al Sulayyim ${ }^{1}$, Ali Al Omari ${ }^{2}$ and Motasim Badri ${ }^{{ }^{*}}$

\begin{abstract}
Introduction: Iron deficiency anemia (IDA) is a global public health issue that affect more than 2 billion individuals worldwide. However evidence for optimal management of IDA is lacking.

Methods: To assess the diagnostic criteria and therapeutic modalities for pediatric IDA employed by physicians in a major public healthcare facility in Riyadh, a validated questionnaire including demographic data and patient casescenarios related to diagnosis and treatment of IDA was employed. Robust regression analysis was used to identify factors associated with overall score of participants.

Results: Of the 166 physicians surveyed 147(88.6\%) were included in the study. Wide variability was observed in IDA diagnosis and therapy practises. For nutritional IDA, only 15.6\% recommended no other laboratory tests in addition to CBC. The majority preferred treatment with ferrous sulfate (77.6\%) divided into two doses (57.1\%), but the total daily elemental iron doses varied widely from 2 to $6 \mathrm{mg} / \mathrm{kg}$. For intravenous iron, $42.9 \%$ recommended iron dextran, $32.7 \%$ iron sucrose, and $13.4 \%$ would continue oral iron. Of all assessed factors, median score was significantly highest in pediatric hematologists compared with pediatricians, family medicine specialists and GPs; $p=0.007$, and those work in tertiary care compared with those in primary care; $p=0.043$. However, in multivariate robust regression analysis, overall score was only significantly associated with professional qualification [pediatric hematologist $\beta=13.71,95 \% \mathrm{Cl}$ 2.48-24.95, $p=0.017$; pediatrician $\beta=1.77,95 \% \mathrm{C}(-6.05-9.59, p=0.66$; family medicine $\beta=2.66,95 \% \mathrm{Cl}-4.30-9.58, p=0.45$ compared with general practitioner].
\end{abstract}

Conclusion: Wide variations exist among physicians in diagnosis and treatment of pediatric IDA. Intervention programs and national guidelines are urgently needed.

Keywords: Iron deficiency anemia, Treatment, Diagnosis, Assessment, Pediatric

\section{Introduction}

Globally, Iron Deficiency (ID) is the most common nutritional deficiency. It affects more than 2 billion individuals in the world. Iron deficiency anemia (IDA) accounts approximately for $50 \%$ of all anemia cases in the world [1]. In developed countries the prevalence of IDA amount to $1-18 \%$ [2], compared with $30-51 \%$ in

\footnotetext{
* Correspondence: motasimb@hotmail.com

'Department of Epidemiology and Biostatistics, College of Public Health and Health Informatics, King Abdulaziz Medical City, Ministry of National Guard Health Affairs, King Saud bin Abdulaziz University for Health Sciences, Riyadh, Kingdom of Saudi Arabia

Full list of author information is available at the end of the article
}

developing countries [3]. Pregnant women, infants aged 4 months to 2 years, young female, vegetarian people, and school-aged children particularly are at increased risk of IDA [4]. Poor dietary and inadequate knowledge among young people are also implicated.

IDA is a consequence of loss of iron, which plays a significant role in normal RBCs synthesis [5]. The process of RBCs production, haematopoiesis, requires iron. About two-thirds of the human body's iron is contained in $\mathrm{Hb}$ [6]. Iron is specifically important for the central nervous system development, particularly at the first 2 years of life. Approximately $80 \%$ of the amount of iron

(C) The Author(s). 2019 Open Access This article is distributed under the terms of the Creative Commons Attribution 4.0 International License (http://creativecommons.org/licenses/by/4.0/), which permits unrestricted use, distribution, and 
in newborns, up to 1 year of age, is accreted during the last 3 months of pregnancy.

A study conducted in the United States found that 9\% of infants aged 1-2 years, and 9-10\% of teenagers had IDA [7]. In some Arabic countries, the prevalence of IDA among infants was above 70\% [8]. However, in the Kingdom of Saudi Arabia (KSA) IDA prevalence among infants who attended well-baby clinics amounted to $52 \%$ [9]. A cross-sectional study conducted in Jeddah estimated an IDA prevalence of $20.5 \%$ among school children [10]. Another study conducted in a northwestern region of KSA found that $49 \%$ of infants aged 6 months to 2 years suffered from IDA [11]. A study conducted among school girls aged between 7 and 14 years in Riyadh reported an IDA prevalence of 26\% [12]. Many studies examining the relationship between IDA and neurological/behavioral developments in children found significant associations between IDA and neurological/ behavioral consequences [12-14].

The American Academy of Pediatrics (APP) recommends that children at 1 year of age should undergo comprehensive screening for anemia. This includes determining $\mathrm{Hb}$ concentration and assessing IDA risk factors. These risk factors include history of low birth weight, continued breastfeeding after 4 months of birth without iron supplementation, decreased socioeconomic status, lead exposures, foods not rich with iron. If the IDA risk factors are noticed in children between one and 3 years, prompt screening should be conducted $[15,16]$.

However, variability still exists in diagnosis of IDA. Many patients undergo unnecessary tests in addition to the complete blood count (CBC) [17]. Some reports emphasized use of hematological parameters such as serum transferrin, serum ferritin (SF), transferrin receptor 1 (TfR1), morphology and number of RBCs and $\mathrm{Hb}$ concentration. Iron status is commonly assessed by SF, while anemia is also commonly assessed by $\mathrm{Hb}$ [18]. SF is considered a sensitive test for Iron stores. The concentration of SF less than $12 \mathrm{~g} / \mathrm{l}$ is considered indicative of ID [19]. However, SF concentration may increase in the presence of some health conditions, such as malignancy, infection, hepatic disease or chronic inflammation. Therefore, it has been recommended that tests not affected by these health conditions, such as C-reactive protein (CRP), Reticulocyte Hemoglobin Content $(\mathrm{CHr})$ or TfR1 must be added as a diagnostic test when the patient is diagnosed with any of these conditions [20]. Although $\mathrm{CHr}$ has been shown to represents a strong biomarker for pediatric ID [21], however, it has been argued that the $\mathrm{CHr}$ test cannot differentiate between IDA and thalassemia, and TfR1 cannot differentiate between IDA and hemolytic anemia. In addition, the TfR1 test is not yet widely available in many countries [21].
Of concern, current therapeutic intervention practice is largely based more on experience than evidence [22] Appropriate iron therapy requires an appropriate dose for enough time duration [23]. An increased $\mathrm{Hb}$ of 1 gram per $\mathrm{dl}$ after 30 days of medication is considered a proper response to therapy and confirms IDA diagnosis. Current available medical literature suggests that 3-6 $\mathrm{mg} / \mathrm{kg} /$ day of iron is an efficient IDA treatment [24, 25]. However, despite being the overwhelming preference for pediatric hematology/oncology specialists, no evidence is available yet to support the choice of iron dosage of 6 $\mathrm{mg} / \mathrm{kg} /$ day in children. Many studies have shown success with low dosages and that higher dose might result in increased adverse events (AEs) and poor adherence [26].Typically, treatment is taken orally, but treatment through parenteral route might be used in IDA patients who cannot tolerate oral route; for instance, those diagnosed with gastrectomy, bariatric surgery, and small intestine surgery [27].

In summary, evidence-based guidelines for optimal management of IDA are lacking. This is because diagnosis of IDA often is challenging, and a highly sensitive and specific diagnostic test currently is not available. In addition, despite the fact that IDA treatment consists initially of oral iron supplement, there is no consensus on the schedule of dosage and the total period of therapy [22].

This study aims to document and analyze the diagnostic criteria and therapeutic modalities employed by pediatricians in healthcare facilities affiliated with the Ministry of National Guard, Riyadh, KSA.

\section{Patients and methods}

An anonymous cross-sectional survey was conducted at healthcare facilities affiliated with the Ministry of $\mathrm{Na}$ tional Guard Health Affairs in the central region of KSA between 16 April and 19 October 2017. These healthcare facilities included primary care [Iskan Clinic, Health Care Specialty Center (HCSC), National Guard Comprehensive Specialized Clinic (NGCSC), Dirab Clinic, and Price Bader primary care clinic (PBRCC)] and tertiary (KASCH). All general practitioners (GP), family medicine physicians, pediatricians, and pediatric hematologists working at these facilities were invited to participate in the study. The purpose of the study was explained in details and those willing to participate signed a formal consent form.

A validated English version questionnaire was used to assess the diagnostic criteria and therapeutic modalities for pediatric IDA employed by each respondent [22]. The questionnaire included two parts. The first part included demographic data and the second part of questionnaire included two case scenarios. The case scenario was presented and the respondent was asked to identify 
the appropriate diagnostic tools and the optimal therapeutic interventions of his/her preference.

The responses were evaluated based on published evidence for diagnosis and treatment of IDA. ${ }^{22,24,28-30}$ An overall score (for diagnosis and treatment, combindly) was calculated for each participant based on his/her response to all items in the questionnaire. The overall score was 19.

\section{Statistical analysis}

Data were presented as proportions (\%) or median (inter-quartile range) and compared using the $X^{2}$ - test, Mann-Whitney test or Kruskal-Wallis Test, as appropriate. The Robust regression analysis method was used to identify variables associated with score. These variables include socio-demographic, professional qualification, professional rank, type of current work setting, years in practice since fellowship, number of co-worker pediatricians and availability of fellowship program at work. Variables found significant in Robust univariate analyses were included in the final multivariate model. All tests were two-sided and a $p$-value $<0.05$ was considered significant. The statistical packages IBMSPSS (release 20) and Stata (StataCorp, Texas, USA, version 15) were used for data management and analysis.

\section{Results}

Of the 166 surveyed, 19 participants were excluded because they did not complete the full questionnaire. Therefore, the final number of participants included in the study was $147(88.6 \%)$.

Socio-demographic and professional characteristics of the participants are shown in Table 1. Median age was 39 [28-43] years and 50.3\% were Males. Most of the respondents were pediatricians $77(52.4 \%)$ and only 6 (4.1\%) were associate consultants. $48.3 \%$ of participants reported their current work setting was a primary care center and $51.7 \%$ a tertiary care center. Approximately $50 \%$ of the participants reported that more than 10 pediatricians' practice at their centers and $60.5 \%$ reported that there was a pediatric fellowship associated with their centers; Table 1.

In case 1, there were wide variations in the diagnostic procedures recommended by participants (Table 2). The majority of respondents recommended additional laboratory tests to the CBC test; SF and TIBC were the most

Table 1 Socio-demographic and professional characteristics of the participants

\begin{tabular}{|c|c|c|c|}
\hline Characteristic & & $N$ & $\%$ \\
\hline Age, Median (Q1-Q3) & & 39.0 & {$[28-46]$} \\
\hline \multirow[t]{2}{*}{ Gender } & $\mathrm{F}$ & 73.0 & 49.7 \\
\hline & M & 74.0 & 50.3 \\
\hline \multirow[t]{4}{*}{ Professional Qualification } & GP & 50.0 & 34.0 \\
\hline & Family medicine & 12.0 & 8.2 \\
\hline & Pediatrician & 77.0 & 52.4 \\
\hline & Pediatric Hematologist & 8.0 & 5.4 \\
\hline \multirow[t]{5}{*}{ Professional Rank } & Assistant Consultant & 22.0 & 15.0 \\
\hline & Associate Consultant & 6.0 & 4.1 \\
\hline & Consultant & 36.0 & 24.5 \\
\hline & staff physician & 48.0 & 32.7 \\
\hline & Resident & 33.0 & 22.4 \\
\hline \multirow[t]{2}{*}{ Type of current work setting } & Primary Care & 71.0 & 48.3 \\
\hline & Tertiary Care & 76.0 & 51.7 \\
\hline \multirow[t]{4}{*}{ Years in practice since fellowship } & $0-5$ years & 58.0 & 39.5 \\
\hline & $6-10$ years & 29.0 & 19.7 \\
\hline & $11-15$ years & 16.0 & 10.9 \\
\hline & $>15$ years & 27.0 & 18.4 \\
\hline \multirow[t]{4}{*}{ No. of co-worker pediatricians } & 1-2 physicians & 47.0 & 32.0 \\
\hline & 3-5 physicians & 19.0 & 12.9 \\
\hline & 6-10 physicians & 7.0 & 4.8 \\
\hline & $>10$ physicians & 74.0 & 50.3 \\
\hline \multirow[t]{2}{*}{ Availability of fellowship program at work place } & No & 55.0 & 37.4 \\
\hline & Yes & 89.0 & 60.5 \\
\hline
\end{tabular}


Table 2 Responses of participants to case 1

Case \#1 A previously healthy 18-month-old male is referred to your clinic for evaluation of anemia. He was exclusively breastfed for 8 months, and since then has been receiving 1-1 1/2 liter whole cow milk daily and limited iron-rich foods. The physical examination is normal except for pallor. His hemoglobin is $8.1 \mathrm{~g} / \mathrm{dL}$, RBC count 4 million/mm3, RDW 20\%, and MCV $58 \mathrm{fL}$. No other laboratory tests were previously performed by the PCP.

\begin{tabular}{clr}
\hline & Respondent answers & $\%$ \\
\hline In addition to a CBC, & which of the following tests would you routinely obtain when first seeing such a patient in your office (Select all \\
1 & No other tests necessary & 15.6 \\
2 & Reticulocyte count & 28.6 \\
3 & Serum Ferritin & 70.7 \\
4 & C-reactive Protein (CRP) & 4.8 \\
5 & Serum Transferrin Saturation & 15.0 \\
6 & Serum Iron & 38.8 \\
7 & Hemoglobin Electrophoresis & 15.6 \\
8 & Serum transferrin receptor & 6.1 \\
9 & Reticulocyte hemoglobin content (CHr or Retic-He) & 3.4 \\
10 & Blood lead level & 0 \\
11 & Total iron binding capacity (TIBC) & 51.0 \\
12 & Other (Please specify) & 2.0
\end{tabular}

Which oral iron preparation would you recommend (assuming insurance and access are not problematic)?

1

2

3

4

5
Ferrous sulphate (Fer-In-Sol ${ }^{\oplus}$, Feromin $^{\circledR}$, Kdiron $\left.^{\oplus}\right)$

Ferrousfumarate (Fumafer ${ }^{\circledR}$, Ferretts $^{\oplus}$ ) 6.8

Ferrous gluconate (Ferrous gluconate ${ }^{\circledR}$, Fergon $^{\circledR}$ ), 3.4

Iron (III)- hydroxide polymaltose (Ferose-F ${ }^{\circledR}$, Ferose $^{\circledR}$ ) 10.2

$\begin{array}{ll}\text { Other (please specify) } & 2.0\end{array}$

Which factors contribute to your recommended oral iron preparation (Select all that apply)?

$1 \quad$ Previous successful experience with it 51.0

$2 \quad$ Medical literature (published clinical studies involving that iron formulation) 44.9

$3 \quad$ Cost / Insurance 16.3

$4 \quad$ Taste / Tolerability 29.3

$5 \quad$ Practice / Recommendation of your partner(s) 16.3

$6 \quad$ Recommendation of the hematologist(s) with whom you trained 16.3

$7 \quad$ Other (please specify) 5.4

What total daily elemental iron dose would you recommend (Select one)?

$\begin{array}{lll}1 & 2-3 \mathrm{mg} / \mathrm{kg} & 27.9 \\ 2 & 4-5 \mathrm{mg} / \mathrm{kg} & 32.0 \\ 3 & 6 \mathrm{mg} / \mathrm{kg} & 32.7 \\ 4 & \text { other (please specify) } & 6.8 \\ 5 & \text { Missing } & 0.6\end{array}$

If the patient's hemoglobin was $6.1 \mathrm{~g} / \mathrm{d}$ (rather than 8.1), what total daily elemental iron dose would you recommend (Select one)?

$\begin{array}{llr}1 & \text { No change } & 8.8 \\ 2 & 2-3 \mathrm{mg} / \mathrm{kg} & 5.4 \\ 3 & 4-5 \mathrm{mg} / \mathrm{kg} & 21.8 \\ 4 & 6 \mathrm{mg} / \mathrm{kg} & 47.6 \\ 5 & \text { other (please specify) } & 15.6 \\ 6 & \text { Missing } & 0.8\end{array}$

If the patient's hemoglobin was $10.1 \mathrm{~g} / \mathrm{dL}$ (rather than 8.1), what total daily elemental iron dose would you recommend (Select one)? 
Table 2 Responses of participants to case 1 (Continued)

\begin{tabular}{|c|c|c|}
\hline & Respondent answers & $\%$ \\
\hline 2 & $2-3 \mathrm{mg} / \mathrm{kg}$ & 34.0 \\
\hline 3 & $4-5 \mathrm{mg} / \mathrm{kg}$ & 24.5 \\
\hline 4 & $6 \mathrm{mg} / \mathrm{kg}$ & 17.7 \\
\hline 5 & other (please specify) & 4.1 \\
\hline 6 & Missing & 0.7 \\
\hline How & e the total daily iron dose (S & \\
\hline 1 & Once daily (QDay) & 34.0 \\
\hline 2 & Divided into 2 doses (BID) & 57.1 \\
\hline 3 & Divided into 3 doses (TID) & 7.5 \\
\hline 4 & Other (please specify) & 0.7 \\
\hline 5 & Missing & 0.7 \\
\hline
\end{tabular}

What is the hemoglobin value below which you would definitely recommend a blood transfusion (assuming the child looks "well compensated" with no co-morbidities) (Select one)?

$\begin{array}{llr}1 & \text { There is no hemoglobin below which I would definitely recommend a blood transfusion } & 21.8 \\ 2 & 3 \mathrm{~g} / \mathrm{dL} & 7.5 \\ 3 & 4 \mathrm{~g} / \mathrm{dL} & 2.0 \\ 4 & 5 \mathrm{~g} / \mathrm{dL} & 14.3 \\ 5 & 6 \mathrm{~g} / \mathrm{dL} & 40.1 \\ 6 & \text { Other (please specify) } & 11.6 \\ 7 & \text { Missing } & 2.7\end{array}$

Case \#1 (continued) At a follow-up visit at 12 weeks, the patient's hemoglobin is $12.2 \mathrm{~g} / \mathrm{dL}, \mathrm{MCV} 78 \mathrm{fL}$ and ferritin $25 \mathrm{ng} / \mathrm{mL}$, and his whole cow milk intake is limited.

Would you recommend continued oral iron therapy (Select one)?

\begin{tabular}{lll}
1 & No & 31.3 \\
2 & Yes, 1-2 additional month of iron therapy & 36.1 \\
3 & Yes, 3 or more additional months of iron therapy & 25.9 \\
4 & Other (please specify) & 4.1 \\
5 & Missing & 2.6 \\
\hline
\end{tabular}

frequent (70.7, 51\%, respectively) recommended additional tests. However, only $15.6 \%$ of the respondents selected the "no other tests necessary" option. Moreover, $2 \%$ of respondents suggested blood film as another additional lab test not include in the list.

Amongst the listed oral iron preparation, most (77.6\%) of the respondents preferred treatment with ferrous sulfate; previous successful experience was the most (51\%) cited reason. In terms of total daily iron dose, the respondents' recommendations were equally distributed across the three listed choices.

Respondents were asked about total daily elemental iron dose they will recommend based on the degree of anemia severity. If the patient's $\mathrm{Hb}$ was $6.1 \mathrm{~g} / \mathrm{dl}$ (rather than $8.1 \mathrm{~g} / \mathrm{dl}$ ), $8.8 \%$ indicated that they would not change the dose. The majority (47.6\%) of the respondents recommended a $6 \mathrm{mg} / \mathrm{kg}$ dose, whereas $5.4 \%$ would choose a $2-3 \mathrm{mg} / \mathrm{dl}$ dose. In case of patient's $\mathrm{Hb}$ was $10.1 \mathrm{~g} / \mathrm{dl}$ (rather than $8.1 \mathrm{~g} / \mathrm{dl}$ ), $19 \%$ indicated they would not change the dosage, whereas the majority (34\%) would choose a $2-3 \mathrm{mg} / \mathrm{dl}$ dose and $24.5 \%$ of the respondents would choose a 4-5 mg/dl dose. In terms of dose frequency, the majority $(57.1 \%)$ recommended 2 doses (BID) and $34 \%$ recommended a once daily dose (QDay).

In regard to recommended course of action for the $\mathrm{Hb}$ value below which blood transfusion should definitely be recommended, for well compensated children, wide variability in responses was found. Approximately 38\% recommended blood transfusion when $\mathrm{Hb}$ value is $6 \mathrm{~g} / \mathrm{dl}$, whereas $21 \%$ responded that there is no $\mathrm{Hb}$ below which they would recommend a blood transfusion. Hb values 
from 3 to $5 \mathrm{~g} / \mathrm{dl}$ were chosen by some respondents in different percentages; 7.5 to $14.3 \%$.

As a continuation of this case scenario, participants were asked whether they will continue oral therapy at the 12th weeks visit if the patient's hemoglobin is $12.2 \mathrm{~g} /$ $\mathrm{dL}, \mathrm{MCV} 78 \mathrm{fL}$ and ferritin $25 \mathrm{ng} / \mathrm{mL}$ and his whole cow milk intake is limited. Approximately $31 \%$ indicated that they will not continue iron therapy, $36.1 \%$ indicated that they will continue iron therapy 1-2 additional month and $25 \%$ they recommend continuation for a further 3 months or more, and $4 \%$ indicated other continuation periods.

In case scenario 2, majority of respondents recommended treatment with ferrous sulfate $(76.2 \%)$ divided into two daily doses $(62.6 \%)$. While $50.3 \%$ of respondents reported that patient's daily dose should be based on weight, $49.7 \%$ recommended that dose should be based on number of tablets. For participants who reported that the daily dose will be based on the number of tablets, approximately $42.5 \%$ reported that they will choose 1 iron tablet daily, $53.4 \%$ reported that they will choose $2-$ 3 iron tablets daily, and $4.1 \%$ reported other numbers of tablets. In terms of those who recommended daily dose should be based on the weight, $32.4 \%$ recommended a $2-3 \mathrm{mg} / \mathrm{kg}$ dose, $58.1 \%$ recommended a $4-5 \mathrm{mg} / \mathrm{kg}$ dose and $6.7 \%$ indicated other doses; Table 3.

In continuation to the case scenario 2, respondents were asked regarding parenteral iron treatment they would recommend in case there is no response to oral iron. Most (42.9\%) respondents indicated IV iron dextran. While $32.7 \%$ of prefer IV iron saccharate, $13.4 \%$ reported that they would continue oral iron therapy. Moreover, $10.9 \%$ of respondents specified some other treatments in the free text comment instead of listed options, including seeking the advice of dietitian, refer to hematologist, and admission for observation.

Correct responses on different questions related to diagnosis and management of IDA are represented in Table 4. Participants were less likely to consider no other laboratory test necessary beyond CBC 23(15.6\%). However, SF had the highest proportion of the preferred lab tests; $71.2 \%$.

Majority of the respondents recognized the appropriate oral iron preparation $(87.8 \%)$ and related factors that should guide their recommendations of the optimum oral iron preparation; $95 \%$. While the vast majority of participants $(99.3 \%)$ could properly divide the total daily iron dose, $68 \%$ were able to identify the total daily elemental iron dose. Percentages of the correct answers related to which total daily elemental iron dose they would choose if the $\mathrm{Hb}$ was $6.1 \mathrm{~g} / \mathrm{dl}$ or $10.1 \mathrm{~g} / \mathrm{dl}$ (rather than $8.1 \mathrm{~g} / \mathrm{dl}$ ) were $78.9,61.9 \%$, respectively. However, they were less likely to know the $\mathrm{Hb}$ value below which they would recommend blood transfusion (33.3\%).
Table 3 Responses of participants to case 2

Case \#2 A previously healthy 13-year-old girl is referred to you for evaluation and treatment of anemia. She experienced menarche 2 years ago and has heavy menstrual periods. She has no evidence of a generalized bleeding disorder, and hormonal regulation has been initiated by her gynecologist. Her physical exam reveals a weight of 65 $\mathrm{kg}$ and mild pallor but is otherwise unremarkable. Her hemoglobin is $9.5 \mathrm{~g} / \mathrm{dL}$ and MCV $65 \mathrm{fL}$. Other laboratory studies and her peripheral smear are consistent with iron deficiency. You again choose to treat with an oral iron product.

Which oral iron preparation would you recommend (Select one)?

\begin{tabular}{|c|c|}
\hline 1 & Ferrous sulphate(Fer-In-Sol ${ }^{\oplus}$, Feromin ${ }^{\oplus}$, Kdiron $\left.{ }^{\oplus}\right)$ \\
\hline 2 & Ferrous fumarate (Fumafer ${ }^{\oplus}$, Ferretts $^{\oplus}$ ) \\
\hline & Ferrous gluconate (Ferrous gluconate ${ }^{\oplus}$, Fergon ${ }^{\circledast}$ ) \\
\hline & Iron (III)- hydroxide polymaltose (Ferose-F®, Ferose $\left.{ }^{\oplus}\right)$ \\
\hline & Other (please specify) \\
\hline & Missing \\
\hline
\end{tabular}

Would this patient's daily dose be based on number of tablets daily or on weight (Select one)?

1 Number of tablets daily

2 Weight-based dosing

Follow-up for persons who chose number of tablets daily: What total daily elemental iron dose would you recommend (Select one)?

$\begin{array}{lll}1 & 1 \text { iron tablet daily } & 42.5 \\ 2 & 2-3 \text { iron tablets daily } & 53.4 \\ 3 & \text { Other (please specify) } & 4.1\end{array}$

Follow-up for persons who choose weight-based dosing: What total daily elemental iron dose would you recommend (Select one)?

$$
\begin{array}{lll}
1 & 2-3 \mathrm{mg} / \mathrm{kg} & 32.4 \\
2 & 4-5 \mathrm{mg} / \mathrm{kg} & 58.1 \\
3 & \text { Other (please specify) } & 9.5
\end{array}
$$

How would you divide the total daily iron dose (Select one)?

$\begin{array}{lll}1 & \text { Once daily (QDay) } & 28.6 \\ 2 & \text { Divided into 2 doses (BID) } & 62.6 \\ 3 & \text { Divided into 3 doses (TID) } & 4.8 \\ 4 & \text { Other (please specify) } & 2.0 \\ 5 & \text { Missing } & 2.0\end{array}$

Case \#2 (continued) The 13 year old patient returns to your clinic 4 weeks after the initial visit. Her last several menstrual periods have been light. She reports that she took the iron medication for several days after her visit with you but then stopped it because of gastrointestinal symptoms. Her laboratory studies are similar to the previous visit. You change to another oral iron preparation, but she continues to have recurrent gastrointestinal symptoms and no improvement in her laboratory studies. You describe parenteral iron treatment options, and she is interested.

Which iron preparation would you recommend (Select one)?

\begin{tabular}{lll}
1 & Intravenous iron dextran (Cosmofer $\left.{ }^{\circledR}\right)$ & 42.9 \\
2 & Intravenous iron saccharate $\left(\right.$ Ferosac$\left.^{\circledast}\right)$ & 32.7 \\
3 & Continued oral iron therapy & 14.3 \\
4 & Other (please specify) & 10.1 \\
\hline
\end{tabular}


Table 4 correct responses on different questions related to diagnosis and management of IDA

\begin{tabular}{|c|c|c|}
\hline Q & & $N(\%)$ \\
\hline \multirow[t]{9}{*}{1} & In addition to a CBC, which of the following tests would you routinely obtain when first seeing such a patient in your office?* & \\
\hline & -No other tests necessary & 23(15.8) \\
\hline & -Reticulocyte count & 42(28.8) \\
\hline & -Serum Ferritin & 104(71.2) \\
\hline & -Serum Transferrin Saturation & $22(15.1)$ \\
\hline & -Serum Iron & $57(39)$ \\
\hline & -Serum transferrin receptor & $9(6.2)$ \\
\hline & -Total iron binding capacity (TIBC) & 75(51.4) \\
\hline & -Other (Blood film) & $3(2.1)$ \\
\hline 2 & Which oral iron preparation would you recommend (assuming insurance and access are not problematic)? & 129(87.8) \\
\hline 3 & Which factors contribute to your recommended oral iron preparation? & $141(95.9)$ \\
\hline 4 & What total daily elemental iron dose would you recommend? & 100(68) \\
\hline 5 & If the patient's hemoglobin was $6.1 \mathrm{~g} / \mathrm{dL}$ (rather than 8.1), what total daily elemental iron dose would you recommend? & 116(78.9) \\
\hline 6 & If the patient's hemoglobin was $10.1 \mathrm{~g} / \mathrm{dL}$ (rather than 8.1), what total daily elemental iron dose would you recommend? & $91(61.9)$ \\
\hline 7 & How would you divide the total daily iron dose? & 146(99.3) \\
\hline 8 & $\begin{array}{l}\text { What is the hemoglobin value below which you would definitely recommend a blood transfusion (assuming the child looks "well } \\
\text { compensated" with no co-morbidities)? }\end{array}$ & 49(33.3) \\
\hline 9 & Would you recommend continued oral iron therapy? & 95(64.6) \\
\hline 10 & Which oral iron preparation would you recommend? & 125(85) \\
\hline 11 & Would this patient's daily dose be based on number of tablets daily or on weight? & $74(50.3)$ \\
\hline 12 & Follow-up for persons who choose weight-based dosing: What total daily elemental iron dose would you recommend? & $43(58.1)$ \\
\hline 13 & How would you divide the total daily iron dose? & 146(99.3) \\
\hline 14 & Which iron preparation (parenteral) would you recommend? & $48(32.7)$ \\
\hline
\end{tabular}

*Represent list of all correct diagnostic tests

Approximately $64 \%$ of the participants identified the correct answer associated with continued iron therapy when the patient improved and lab result showed normal $\mathrm{Hb}, \mathrm{MCV}$, and ferritin values. For case scenario 2, a high proportion identified the correct oral iron preparation (85\%), and only half of them were able to indicate the correct daily dose. However, $58.1 \%$ of them had positive knowledge about weight-based dose. While $99.3 \%$ of participants could know the correct division of the total daily iron dose, only $32.7 \%$ of them identified the optimum parenteral iron treatment.

Differences in overall median scores of correct answers by demographic and professional characteristics are represented in Table 5. Overall scores differed significantly by professional qualification $(P=0.007)$ and type of current work setting $(P=0.043)$.

Robust regression analysis for factors associated with overall score is represented in Table 6. In univariate analysis, professional qualification and type of current work setting were the only two variables statistically significantly associated with overall score. In the final multivariate analysis model, the only variable that was independently significantly associated with increased overall scores was professional qualification $(P=0.017)$. Score of Pediatric Hematologists was 14.98 times higher than score of GPs $(\beta=14.98$, CI 6.81-23.15, $P<0.0001)$. Compared with scores of participants who work in primary care, score of participants who work in tertiary care was 3.63 times higher $(\beta=3.63, \mathrm{CI}-0.03-7.28, \mathrm{P} 0.05)$.

Based on findings of the above detailed regression analysis, further analyses were carried out to fully describe differences in scores both in the diagnostic and therapeutic domains questions by professional qualifications and type of current work setting. Consistently, the proportion of those achieved highest score of correct answers were pediatric hematologists, compared with respondents with other professional qualifications. General Practitioners had the lowest proportion. Moreover, participants who work in tertiary care had significantly higher proportion of those achieved highest score of correct answers compared with those who work in primary care.

\section{Discussion}

To the best of our knowledge, this is the first study conducted in the Arabian Gulf region to assess the diagnostic and therapeutic modalities employed by physicians 
Table 5 Differences in overall scores by demographic and professional characteristics

\begin{tabular}{|c|c|c|c|c|}
\hline \multirow[t]{2}{*}{ Characteristics } & & \multicolumn{3}{|c|}{ Overall Score } \\
\hline & & Median & $(\mathrm{Q} 1, \mathrm{Q} 3)$ & $p$ \\
\hline \multirow[t]{2}{*}{ Gender } & Female & 68 & $(63-74)$ & $0.217^{*}$ \\
\hline & Male & 68 & $(63-79)$ & \\
\hline \multirow[t]{4}{*}{ Professional qualification } & GP & 63 & $(63-74)$ & $0.007+$ \\
\hline & Family medicine & 68 & $(61-76)$ & \\
\hline & Pediatrician & 68 & $(63-79)$ & \\
\hline & Pediatric Hematologist & 84 & $(71-89)$ & \\
\hline \multirow[t]{5}{*}{ Professional rank } & Assistant consultant & 74 & $(63-79)$ & $0.413+$ \\
\hline & Associated consultant & 68 & $(63-74)$ & \\
\hline & consultant & 68 & $(63-76)$ & \\
\hline & Staff physician & 63 & $(63-74)$ & \\
\hline & Resident & 68 & $(58-74)$ & \\
\hline \multirow[t]{2}{*}{ Type of current work setting } & primary care & 63 & $(63-74)$ & $0.043^{*}$ \\
\hline & Tertiary care & 68 & $(63-79)$ & \\
\hline \multirow[t]{4}{*}{ Years in practice since fellowship } & $0-5$ years & 68 & $(58-74)$ & $0.848+$ \\
\hline & $6-10$ years & 68 & $(63-79)$ & \\
\hline & $11-15$ years & 68 & $(61-76)$ & \\
\hline & $>15$ years & 68 & $(63-79)$ & \\
\hline \multirow[t]{4}{*}{ No. of co-worker pediatricians } & 1-2 physicians & 63 & $(58-74)$ & $0.188+$ \\
\hline & 3-5 physicians & 68 & $(63-68)$ & \\
\hline & 6-10 physicians & 74 & $(68-79)$ & \\
\hline & $>10$ physicians & 68 & $(63-79)$ & \\
\hline \multirow[t]{2}{*}{ Availability of Fellowship program at work place } & No & 68 & $(63-74)$ & $0.813^{*}$ \\
\hline & Yes & 68 & $(63-79)$ & \\
\hline
\end{tabular}

* Mann-Whitney Test tKruskal-Wallis Test Q1-Q3: first and third quartiles

for the management of pediatric IDA. The study findings show wide variations in practices and recommendations regarding the proper diagnosis and treatment of pediatric IDA in KSA by physicians involved in management and care. This reflects lack of local guidelines for management of this widely prevalent medical condition. National guidelines are urgently needed. Further, the study identifies some healthcare practitioners who might benefit from further training to improve their pediatric IDA management skills. Namely, physicians working in primary care setting, GPs, family medicine practitioners and pediatricians.

Research work on diagnostic criteria and therapeutic modalities employed by physicians for pediatric IDA is

Table 6 Factors associated with overall score

\begin{tabular}{|c|c|c|c|c|c|}
\hline \multirow[t]{2}{*}{ Factor } & \multirow[t]{2}{*}{$N(\%)$} & \multicolumn{2}{|l|}{ Univariate analysis } & \multicolumn{2}{|c|}{ Multivariate analysis } \\
\hline & & $\overline{\beta(95 \% \mathrm{Cl})}$ & $p$ & $\overline{\beta(95 \% \mathrm{Cl})}$ & $p$ \\
\hline \multicolumn{6}{|l|}{ Professional qualification } \\
\hline Pediatric hematologist & $8(5.4)$ & $14.98(6.81,23.15)$ & $<0.0001$ & $13.71(2.48,24.95)$ & 0.017 \\
\hline Pediatrician & $77(52.4)$ & $2.87(-1.02,6.77)$ & 0.15 & $1.77(-6.05,9.59)$ & 0.66 \\
\hline Family medicine & $12(8.2)$ & $2.69(-4.20,9.58)$ & 0.44 & $2.66(-4.30,9.58)$ & 0.45 \\
\hline General practitioner & $50(34)$ & 1 & & 1 & \\
\hline \multicolumn{6}{|c|}{ Type of current work setting } \\
\hline Tertiary & $76(51.7)$ & $3.63(-0.03,7.28)$ & 0.05 & $1.26(-6.40,8.92)$ & 0.75 \\
\hline Primary & $71(48.3)$ & 1 & & 1 & \\
\hline
\end{tabular}


sparse. While previous studies focused on IDA epidemiology [1, 7, 8, 12, 29], diagnosis [24, 29-31], treatment $[24,32]$, or prevention $[28,29,33]$, findings of our study and another study conducted in U.S by Powers et al. [17] were the only two studies to demonstrate a wide variation among physicians in IDA diagnosis and treatment. However, compared with Powers et al. study, the present study adopted a unique approach. The total score we calculated in this study, based on participants responses to different questions, allowed us to identify various sub-optimal practices regarding diagnosis and treatment of pediatric IDA.

The documented wide variations in this study regarding the diagnostic criteria for IDA worth consideration. Many of the patients managed at primary care facilities or referred to tertiary hospitals undergo unnecessary tests in addition to the CBC [31]. The study finding that only $15.6 \%$ of participants in the present study recommended that no additional laboratory tests necessary beyond the $\mathrm{CBC}$ concur with findings of a study conducted in the U.S. by Powers J et al. [17]They also found a similar percentage of $15 \%$.

AAP guidelines recommend that patient found anemic on initial screening should undergo confirmative testing for dubious IDA that include measuring TfR1 concentration, CHr or Ret-He, and/or SF with CRP [29]. However, the AAP does not indicate that neither $\mathrm{CHr}$ cannot differentiate between IDA and thalassemia nor TfR1 cannot differentiate between IDA and hemolytic anemia [34]. Further, these tests are not readily available in all healthcare centers, particularly in resource-limited countries. Therefore, making a clinical decision based on such tests might not be viable. In this study, most participants do not use a specific guidelines to confirm diagnosis of IDA. In the aforementioned U.S. study which surveyed pediatric hematology/oncology physicians, most participants did not employ the AAP's approach [17]. Powers et al. recommended that $\mathrm{CBC}$, peripheral blood smear and reticulocyte count along with serum iron, SF and TIBC usually can be used to establish the diagnosis of IDA [23]. While such tests were chosen by over $50 \%$ of Powers et al. study participants, SF and TIBC were selected by approximately half of our participants.

In regard IDA treatment, elicited responses indicate that over half of our study participants base their therapeutic decision on their previous experience than on evidence. Almost all published literature recommends a dose of $3-6 \mathrm{mg} / \mathrm{kg} /$ day of iron as an efficient IDA treatment $[24,30]$. However despite using $6 \mathrm{mg} / \mathrm{kg} /$ day being the overwhelming preference for pediatric hematology oncology specialists, there is no evidence base for such choice. Many studies have shown treatment success with low dosages. A randomized trial in Ghana compared patients to $40 \mathrm{mg}$ of iron, or almost $3 \mathrm{mg} / \mathrm{kg} /$ day either as a single dosage or in three divided dosages, found similar success in both groups [32].Another study including 90 elderly patients compared three daily doses of iron $(15 \mathrm{mg}, 50 \mathrm{mg}$, and $150 \mathrm{mg}$ ). After 60 days, in all three groups, the increases in $\mathrm{Hb}$ concentration and SF were similar. This suggests that low oral dosage of iron treatment could be as effective as high dosage. Furthermore, in the lowest dose groups, the rates of dropout and adverse effects were lower [35].However, the optimal duration for oral iron supplementation has not been specified yet but previous studies recommend 3-6 months supplementation $[25,26,36]$. Canadian Pediatric Surveillance Program recommends $6 \mathrm{mg} / \mathrm{kg} /$ day of oral iron dose for 3-4 months [44]. It has been suggested that Iron stores are refilled after continuation of iron therapy for 2-3 months [36].

Responses of participants showed a marked variability regarding the duration of continued oral iron treatment when the patient's $\mathrm{Hb}, \mathrm{MCV}$ and ferritin became normal. This is comparable to Powers et al. study [17]. However, in this study, $50.3 \%$ of respondents recommended patient's daily dose should be based on weight and $49.7 \%$ based on number of tablets compared with 64 and 36\% respectively in that study. Although the Food and Drug Administration (FDA) approved many safe and effective parenteral iron preparations for adult patients and children who could not responded to oral iron therapy, only $14 \%$ of participants in the present study recommended this course of action. Approximately, of 170 iron therapies used to treat and prevent IDA, ferrous sulfate was most effective and least cost compared with other oral iron treatments [37].Currently, it is the most frequent treatment for IDA's patients [23].

Study participants received very low scores on other two items of the questionnaire. In the question regarding the $\mathrm{Hb}$ value below which they would definitely recommend a blood transfusion (assuming the child looks "well compensated" with no co-morbidities), only 33.3\% identified the correct strategy. Indeed, there is no globally agreed threshold in terms of the blood transfusion, and hence, some physicians recommend blood transfusion based on symptoms and clinical condition regardless of the $\mathrm{Hb}$ values [45]. Further, regarding which parenteral iron preparation should be used, only $32.7 \%$ of the participants indicated the correct IV preparation. Relevant studies indicate that IV administration of iron dextran increases $\mathrm{Hb}$ in 7-14 days [38], and iron saccharate (iron sucrose) and ferric gluconate increases the $\mathrm{Hb}$ after 7 days [39].Clinical trials conducted to detect AEs after administering iron sucrose [40], ferric gluconate [41] and iron dextran [42] reported a frequency of 36,35 , and $50 \%$ among study participants, respectively. Another study conducted by Sayyad et al. found that 
administration of the iron sucrose was not associated with serious AEs [46]. Further, iron sucrose and ferric gluconate found to be better than iron dextran in term of higher bio-availability and lower occurrence of anaphylaxis which is considered life-threatening [43]. Consequently, using iron dextran was restricted in the U.S. due to its multiple AEs, such as anaphylactic reactions $[47,48]$. However, these low proportions of correct answers maybe explained by the fact that most GPs, family physicians, and some pediatricians transfer their patients to a pediatric hematologist in cases of transfusion or IV iron preparation. This concurs with our findings that higher scores were achieved by pediatric hematologists and those working in tertiary care setting. In the final multivariate robust regression analysis model pediatric hematologists score of was 14.98 times higher than that of general practitioners.

This study has some limitations. The study represents assessment of GPs, family physicians, pediatricians and pediatric hematologists who work in single healthcare facility in KSA and might not be generalizable to practitioners in other national healthcare facilities. No other similar local data are available to confirm the findings of this study. Although the response rate of participation is high (88\%), responses of those declined to complete the questionnaire might be different from those retained in this study. This might have introduced, albeit minimum, ascertainment bias. However, those who declined participation are not likely to be different from those who participated in the study. The assessment of responses was based on local expert opinion and limited international published studies and might not reflect a global consensus on management of pediatric IDA.

\section{Conclusion}

A wide variation exists in diagnostic and treatment modalities employed by physicians for pediatric IDA in KSA. This is further exasperated by lack of evidencebased guidelines for the optimal management of this widely diagnosed medical condition. These guidelines are urgently needed. Large scale clinical trials and prospective studies are needed to better inform these guidelines and programs. The study identifies certain healthcare professionals that might benefit from intervention programs aimed at maximizing optimal management of IDA patients.

\section{Abbreviations}

AEs: Adverse events; APP: American Academy of Pediatrics; CBC: Complete blood count; CHr: Reticulocyte Hemoglobin Content; CRP: C-reactive protein; FDA: Food and Drug Administration; GP: General practitioner; Hb: hemoglobin; ID: Iron Deficiency; IDA: Iron deficiency anemia; IV: Intra venous; KSA: Kingdom of Saudi Arabia; MCV: Mean Corpuscular Volume; QDay: Once daily dose; RBC: Red blood cells count; SF: serum ferritin; TfR1: Transferrin receptor 1

\section{Acknowledgments}

We would like to thank Dr. Ali Al Farhan and Dr. Saeed Ur-Rahman for facilitating the distribution of the questionnaire for study participants at the different healthcare facilities affiliated with the Ministry of National Guard, Riyadh, KSA.

\section{Authors' contributions}

HJAS, MB and AAO conceptualized and designed the study. HJAS performed the field work and data collection. HJAS performed the statistical analysis under the supervision of $\mathrm{MB}$ and drafted the final manuscript. All authors contributed to revision of final manuscript and approved submission.

Funding

This research work was not funded.

\section{Availability of data and materials}

The datasets used and/or analyzed during the current study are available from the corresponding author on reasonable request.

\section{Ethics approval and consent to participate}

This study was approved by King Abdullah International Medical Research Center (KAIMRC) Research Ethics Committee (protocol number SP17/045/R). All participants filled a consent form to participate in the study.

\section{Consent for publication}

Not applicable.

\section{Competing interests}

The authors declare that they have no competing interests.

\section{Author details}

'Department of Epidemiology and Biostatistics, College of Public Health and Health Informatics, King Abdulaziz Medical City, Ministry of National Guard Health Affairs, King Saud bin Abdulaziz University for Health Sciences, Riyadh, Kingdom of Saudi Arabia. ${ }^{2}$ Division of Pediatric, Department of Oncology, King Abdulla Specialized Children Hospital, King Abdulla International Medical Research Centre, Riyadh, Saudi Arabia.

Received: 3 July 2019 Accepted: 30 August 2019

Published online: 05 September 2019

References

1. McLean E, Cogswell M, Egli I, Wojdyla D, de Benoist B. Worldwide prevalence of anaemia, WHO vitamin and mineral nutrition information system, 1993-2005. Public Health Nutr. 2009;12(4):444-54.

2. Thorsdotir I, Gunnarsson BS, Atladottir H, Michaelsen KF, Palsson G. Iron status at 12 months of age -- effects of body size, growth and diet in population with high birth weight. Eur J ClinNutr. 2003;57(4):505-13.

3. Brotanek JM, Gosz J, Weitzman M, Flores G. Iron deficiency in early childhood in the United States: risk factors and racial /ethnic disparities. Pediatrics. 2007;120(3):568-75.

4. Buonomo E, Cenko F, Altan AM, Godo A, Marazzi MC, Palombi L. Iron deficiency anemia and feeding practice in Albanian children. Ann Ig. 2005; 17(1):27-33

5. Musaiger AO. The state of food and nutrition in the Arabian gulf countries. World Rev Nutr Diet. 1987;54:105-73.

6. Lozoff B, Kaciroti N, Walter T. Iron deficiency in infancy: applying a physiologic framework for prediction. Am J ClinNutr. 2006;84(6):1412-21.

7. Burden MJ, Westerlund AJ, Armony-Sivan R, Nelson CA, Jacobson SW, Lozoff B, et al. An event-related potential study of attention and recognition memory in infants with iron-deficiency anemia. Pediatrics. 2007;120(2):e336-45.

8. Looker AC, Dallman PR, Carroll MD, Gunter EW, Johnson CL. Prevalence of iron deficiency in the United States. JAMA. 1997 26;277(12):973-6.

9. Kibride J, Baker TG, Parapia LA, Khoury SA. Incidence of iron deficiency anemia in infants in a prospective study in Jordan. Eur J Haematology. 2000; 64(4):231-6

10. Al Hifzi I, Pejaver RK, Qureshi I. Screening for iron deficiency anemia in a well-baby clinics. Ann Saudi Med. 1996;16(6):622-4. 
11. Abalkhail B, Shawky S. Prevalence of daily breakfast intake, iron deficiency anaemia and awareness of being anaemic among Saudi school students. Int J Food SciNutr. 2002;53(6):519-28.

12. Al Hawsawi ZM, Al Rebali SA, Mabros AM, Al Asiri AM, Al Harbi KD, Yousef AM. High prevalence of iron deficiency anemia in infants attending a wellbaby clinic in northwestern Saudi Arabia. Saudi Med J. 2015;36(9):1067-70.

13. Al-Othaimeen A, Osman AK, Al OS. Prevalence of nutritional anaemia among primary school girls in Riyadh City. Saudi Arabia Int J Food SciNutr. 1999:50(4):237-43.

14. Idjradinata P, Pollitt E. Reversal of developmental delays in iron-deficient anemic infants treated with iron. Lancet. 1993:341(8836):1-4.

15. Lozoff B, Jimenez E, Hagen J, Mollen E, Wolf AW. Poorer behavioral and developmental outcome more than 10 years after treatment for iron deficiency in infancy. Pediatrics. 2000;105(4):E51.

16. Cusick SE, Mei Z, Freedman DS, Looker AC, Ogden CL, Gunter E, et al. Unexplained decline in the prevalence of anemia among US children and women between 1988-1994 and 1999-2002. Am J ClinNutr. 2008;88(6): 1611-7.

17. Oski FA. Iron deficiency in infancy and childhood. N Engl J Med. 1993; 329(3):190-3.

18. De-Regil LM, Jefferds ME, Sylvetsky AC, Dowswell T. Intermittent iron supplementation for improving nutrition and development in children under 12 years of age. Cochrane Database Syst Rev. 2011;7(12):CD009085.

19. Worwood M. Indicators of the iron status of populations: ferritin. In: CDC WHO, editor. Assessing the Iron Status of Populations: Report of a Joint World Health Organization/Centers for Disease Control and Prevention Technical Consultation on the Assessment of Iron Status at the Population Level. 2nd ed. Geneva: World Health Organization; 2007. p. 35-74.

20. Dallman PR, Siimes MA, Stekel A. Iron deficiency in infancy and childhood Am J ClinNutr. 1980:33(1):86-118.

21. Ullrich C, Wu A, Armsby C, Rieber S, Wingerter S, Brugnara C, et al. Screening healthy infants for iron deficiency using reticulocyte hemoglobin content. JAMA. 2005;294(8):924-30.

22. Short MW, Domagalski JE. Iron deficiency anemia: evaluation and management. Am Fam Physician. 2013;87(2):98-104.

23. Skikne BS, Flowers $\mathrm{CH}$, Cook JD. Serum transferrin receptor: a quantitative measure of tissue iron deficiency. Blood. 1990;75(9):1870-6.

24. Andrews N, Ullrich C, Fleming M. Disorders of Iron Metabolism and Sideroblastic Anemia. In: Orkin SH, Nathan DG, Ginsburg D, ATL, Fisher DE, Lux SE, IV, editors. Nathan and Oski's Hematology of Infancy and Childhood. 7. Philadelphia: Sunders Elsevier; 2009. p. 521-42.

25. Grant CC, Wall CR, Brewster D, Nicholson R, Whitehall J, Super L, et al. Policy statement on iron deficiency in pre-school-aged children. J Paediatr Child Health. 2007:43(7-8):513-21.

26. Rimon E, Kagansky N, Kagansky M, Mechnick L, Mashiah T, Namir M, et al. Are we giving too much iron? Low-dose iron therapy is effective in octogenarians. Am J Med. 2005;118(10):1142-7.

27. Auerbach M, Adamson JW. How we diagnose and treat iron deficiency anemia. Am J Hematol. 2016;91(1):31-8.

28. Crary SE, Hall K, Buchanan GR. Intravenous iron sucrose for children with iron deficiency failing to respond to oral iron therapy. Pediatr Blood Cancer. 2011:56(4):615-9.

29. United Nations Children's Fund, United Nations University, World Health Organization. Iron deficiency anaemia. Geneva: World Health Organization: Assessment, prevention and control, a guide for programme managers; 2001.

30. Powers JM, Buchanan GR. Diagnosis and management of iron deficiency anemia. HematolOncolClin North Am. 2014;28(4):729-45.

31. Centers for Disease Control and Prevention. Iron deficiency: United States, 1999-2000. MMWR Morb Mortal Wkly Rep. 2002; 51(40): 897-899.

32. Heeney M. Anemia. In: Rudolph, AM.; Lister, GE.; first, LR.; AAG, editors. Rudolph's pediatrics. New York: McGraw-Hill; 2011.

33. Baker RD, Greer FR. Diagnosis and prevention of iron deficiency and irondeficiency anemia in infants and young children ( $0-3$ years of age). Pediatrics. 2010;126(5):1040-50.

34. Powers JM, McCavit T, Buchanan GR. Management of iron deficiency anemia: a survey of pediatric hematology/oncology specialists. Pediatr Blood Cancer. 2015;62(5):842-6.

35. Zlotkin S, Arthur P, Antwi K, Yeung G. Randomized, controlled trial of single versus 3-times-daily ferrous sulfate drops for treatment of anemia. Pediatrics. 2001;108(3):613-6.
36. SMITH NJ. Iron as a therapeutic agent in pediatric practice. J Pediatr. 1958, 53(1):37-50.

37. Buchanan GR. Paucity of clinical trials in iron deficiency: lessons learned from study of VLBW infants. Pediatrics. 2013;131(2):e582-4.

38. Murphy MF, Wallington TB, Kelsey $P$, Boulton F, Bruce $M$, Cohen $H$, et al. British Committee for Standards in Haematology, blood transfusion task Force.Guidelines for the clinical use of red cell transfusions. Br J Haematol. 2001;113(1):24-31.

39. Yee J, Besarab A. Iron sucrose: the oldest iron therapy becomes new. Am J Kidney Dis. 2002;40(6):1111-21

40. Charytan C, Leven N, Al-Saloum M, Hafeez T, Gagnon S, Van Wyck DB. Efficacy and safety of iron sucrose for iron deficiency in patients with dialysis-associated anemia. North American clinical trial. Am J Kidney Dis. 2001;37(2):300-7.

41. Hood SA, O'Brien M, Higgins R. The safety of intravenous iron dextran (Dexferrum) during hemodialysis in patients with end stage renal disease. NephrolNurs J. 2000;27(1):41-2.

42. Michael B, Coyne DW, Fishbane S, Folkert V, Lynn R, Nissenson AR, et al. Sodium ferric gluconate complex in hemodialysis patients: adverse reactions compared to placebo and iron dextran. Kidney Int. 2002;61(5): 1830-9

43. Siddiqui SS, Jaybhaye DL, Kale A, Kakade J, Engade M, Haseeb M. Efficacy and safety of intravenous iron sucrose therapy in group of children with iron deficiency anemia. Int J Contemp Pediatrics. 2015;2(1):12-6.

44. Pasricha SR, Flecknoe-Brown SC, Allen KJ, Gibson PR, McMahon LP, Olynyk $\mathrm{JK}$, et al. Diagnosis and management of iron deficiency anaemia: a clinical update. Med J Aust. 2010;193(9):525-32.

45. Abdullah K, Zlotkin S, Parkin P, Grenier D. Iron-deficiency anemia in children. Canadian: Pediatric Surveillance program; 2001. https://www.cpsp.cps.ca/ uploads/publications/RA-iron-deficiency-anemia.pdf. Accessed 25 Dec 2017

46. Ifudu O. Parenteral iron: pharmacology and clinical use. Nephron. 1998;80(3) 249-56.

47. Johnson-Wimbley TD, Graham DY. Diagnosis and management of iron deficiency anemia in the 21st century. Therap.Adv.Gastroenterol. 2011;4(3): 177-84.

48. Chertow GM, Mason PD, Vaage-Nilsen O, Ahlmén J. Update on adverse drug events associated with parenteral iron. Nephrol Dial Transplant. 2006; 21(2):378-82.

\section{Publisher's Note}

Springer Nature remains neutral with regard to jurisdictional claims in published maps and institutional affiliations.

\section{Ready to submit your research? Choose BMC and benefit from:}

- fast, convenient online submission

- thorough peer review by experienced researchers in your field

- rapid publication on acceptance

- support for research data, including large and complex data types

- gold Open Access which fosters wider collaboration and increased citations

- maximum visibility for your research: over $100 \mathrm{M}$ website views per year

At BMC, research is always in progress.

Learn more biomedcentral.com/submission 